\title{
Melacak Jejak Radikalisme dalam Islam: Akar Ideologis dan Eksistensinya dari Masa ke Masa
}

\author{
Sony Amrullah \\ Sekolah Tinggi Ilmu Syari’ah Faqih Asy'ari Kediri, Indonesia \\ Email: Soniamrullah@gmail.com
}

\begin{abstract}
Radicalism is an extreme attitude shown in the effort to defend ideology. Radicalism is often accompanied by extreme attitudes such as violence, coercion, and terror to groups that are considered opposed to their ideology. Historically, Islam has also given birth to people who are disproportionate in religion so they can be called as radical figures and groups in Islam. Traces of radicalism in Islam can be traced its existence even starting from the early formation of Islam that is the period of propagation of the Prophet Muhammad SAW. This extreme attitude then continues to live and evolve and even establish its existence by forming a particular group. Ironically, this radical group that pursues the purification of Islam is alive and growing to this day. This paper seeks to explore traces of Islamic radicalism from the period of the Prophet Muhammad SAW, the period of companions, to the contemporary period.
\end{abstract}

Keywords: radicalism, ideology, islam

\section{Pendahuluan}

Mengaitkan antara Islam dan Ekstrimisme memang tidaklah mudah. Pertanyaan yang segera muncul adalah, apakah Islam mengajarkan ekstrimisme atau radikalisme?. Jawaban atas pertanyaan tersebut selalu problematik. Sebab agama (Islam maupun agama apapun) secara taken for granted dipandang sebagai instrumen ilahiah yang mengajarkan hal-hal yang serba "baik". Bagaimana mungkin kita bisa mengaitkan agama dengan ekstrimisme, sesuatu yang secara inheren mengandung hal-hal yang tidak biasa dan seringkali dipandang secara pejorative. Dalam hal ini agama dan ekstrimisme sering dilihat sebagai kontradiktif. Namun demikian, dalam kenyataan sehari-hari, kaitan erat antara agama dan ekstrimisme merupakan hal yang mudah ditemui. ${ }^{1}$

Pernyataan di atas sesungguhnya merupakan segelintir kegelisahan atas banyak muncul dan merebaknya sikap ekstrimisme atau radikalisme yang banyak ditujukan kepada salah satunya Islam. Terlepas apakah akar radikalisme muncul atas tafsir sekelompok orang tentang doktrin agama, ataukah ada kepentingan tertentu sehingga menyebabkan mereka berlaku ekstrim dan radikal, jelasnya sikap radikal nyatanya merupakan sikap destruktif yang banyak merugikan tidak terkecuali bagi umat Islam sendiri.

Radikalisme yang berujung pada perilaku takfirisme yang menganggap orang lain yang berbeda pandangan dari segi apapun baik teologis, hukum, bahkan pandangan-pandangan tentang negara mereka anggap sebagai kafir merupakan fenomena yang telah terjadi sejak lama bahkan dapat dilacak jauh pada fase formasi Islam awal yakni pada periode dakwah Nabi Muhammad Saw.

Menurut Azra sebagaimana dikutip Ratnasari, pelacakan historis gerakan fundamentalisme awal dalam Islam bisa dirujukkan kepada gerakan Khawarij, sedangkan representasi gerakan fundamentalisme kontemporer bisa dialamatkan kepada gerakan Wahabi Arab Saudi dan Revolusi Islam Iran. ${ }^{2}$ Akan tetapi, sifat yang sedemikian sudah terlihat pada masa Nabi Muhammad. Hal inilah yang oleh Nayif Mahmud Ma'ruf disebut sebagai akar-akar

\footnotetext{
2 Dwi Ratnasari, Fundamentalisme Islam (Jurnal KomunikaVol.4 No.1 Januari-Juni 2010), 43
}

\footnotetext{
${ }^{1}$ Mun'im A Sirry, Membendung Militansi Agama: Iman dan Politik dalam Masyarakat Modern (Jakarta: Erlangga, 2003), 30
} 
Khawarij (radikalisme Islam). Menurutnya, hampir semua perawi hadits menyepakati adanya prediksi Nabi Muhammad mengenai kemunculan Khawarij (radikalisme Islam). ${ }^{3}$

Dalam banyak analisis, sikap keras, rigid, dan cenderung literal dalam mempraktikkan agama serta banyak melakukan tindakan-tindakan represif terhadap berbagai kelompok yang berseberangan dengan mereka yang banyak dipraktikkan kelompok "keras" ini, timbul kerangka membela agama secara total. Namun demikian banyak juga motif-motif lain yang bersifat duniawi misalkan harta, kedudukan, dan posisi di masyarakat.

Tulisan ini berusaha mengkaji dan menganalisis berbagai pemikiran ataupun gerakan radikalisme, baik yang dilakukan individu maupun berkelompok mulai dari periode Nabi Muhammad Saw, sahabat, hingga masa modern.

Tujuan tulisan ini ialah memberikan gambaran yang komprehensif mengenai akar ideologis gerakan radikalisme dalam Islam dari masing-masing periode kemunculannya dari periode Nabi Saw hingga gerakan radikalisme kontemporer, dampak kemunculan gerakan radikal, sekaligus memberikan alternatif solusi atas munculnya gerakan-gerakan radikalisme dalam Islam.

\section{Akar Ideologis Radikalisme Islam}

Secara teoretis, 'radikal' adalah sikap. Sama seperti sikap 'disiplin' militer atau 'rajin' belajar. Sikap radikal adalah perasaan (afeksi) yang positif terhadap segala yang serba ekstrim, sampai keakar-akarnya. Sikap ini akan mendorong motivasi dan perilaku ke arah membela mati-matian apa yang dianggapnya sebagai nilai-nilai yang paling mendasar dari suatu keyakinan, kepercayaan, ideologi, atau agama, atau apa saja. ${ }^{4}$

\footnotetext{
${ }^{3}$ Nayif Mahmud Ma'ruf, al-Khawarij fial-'Asr al-Umawi (Beirut: Dar al-Tali'ah, 1994), 14

${ }^{4}$ Sarlito Wirawan Sarwono, Terorisme di Indonesia dalam Tinjauan Psikologis (Jakarta: Pustaka Alvabet, 2012), 130

${ }^{5}$ Lihat Haidar Bagir, Islam Tuhan, Islam Manusia: Agama dan Spiritualitas di Zaman Kacau (Bandung: Mizan, 2017), 49-55
}

Semua pemikiran dan gerakan apapun bentuknya, baik yang terorganisir maupun yang berlangsung secara sporadis saja, pastilah memiliki rangkaian akar ideologis yang berfungsi sebagai landasan dan legitimasi atas gerakan tersebut, pun tidak terkecuali pada gerakan radikalisme dalam Islam.

Dalam mengurai akar ideologis radikalisme dalam Islam, Haidar Bagir memberikan pendapatnya bahwa, setidaknya terdapat dua faktor penting yang menjadi penyebab muncul dan menguatnya radikalisme dalam Islam yakni ${ }^{5}$ :

\section{Dokrinal Historis}

Doktrin takfiriyyah dapat dengan mudah dilacak sebagai berakar pada cara pandang terhadap agama yang menekankan pada aspekaspek keras dan kaku hukum-hukum keagamaan. Sebagai akibatnya, berkembang sikap eksklusif dalam bentuk kecenderungan untuk mengeluarkan kelompok lain dari apa yang diyakini sebagai umat pemeluk suatu agama. Lebih dari itu, muncul pula dengan kuat rasa keharusan untuk menghukum orangorang yang dianggap sebagai membangkang terhadap ajaran Tuhan (kafir) ini, dan kalau perlu, mencabut hak mereka untuk hidup di bumi-Nya.

\section{Sosial-Politik}

Radikalisme yang kebanyakan diiringi oleh sikap takfirisme kontemporer ini kiranya juga dipantik oleh ketimpangan politik dan ekonomi $^{6}$ dimana kelompok keagamaan memiliki atau, setidak-tidaknya dianggap demikian akses istimewa kepada pemerintahan, kekayaan, posisi penting di pemerintahan dan kehidupan kultural. Kontestasi pengaruh di tubuh umat Islam ini dipertajam oleh keterlibatan pemerintahanpemerintahan asing Amerika dan Eropa yang tidak ingin kehilangan cengkeramannya di

\footnotetext{
${ }^{6}$ Pernyataan ini juga diamini oleh Mulkhan bahwa praktik keagamaan penuh simbol dengan ritual formal atau disertai kekerasan, radikal atau penuh bid'ah, dan praktik sinkretik akan meluas di tengah kesenjangan sosial-ekonomi yang menajam dan krisis sosial multi dimensi. Lihat Abdul Munir Mulkhan, Sufi Pinggiran: Menembus Batas-Batas (Yogyakarta: Kanisius, 2007), 17
} 
wilayah ini dengan mendukung rezim-rezim tertentu sejauh dapat mengamankan kepentingan politik dan ekonomi mereka.

Faktor yang tak bisa diabaikan dalam menguatnya gejala ekstremisme ini ialah "perang dingin" antara Sunni Arab Saudi dan Syi'ah Iran untuk memobilisasi dukungan regional. Saudi di satu pihak memposisikan diri sebagai pelindung kaum Sunni, sementara di pihak lain, Teheran secara alami mencari sekutu-sekutu di antara komunitas Syi'ah yang hidup di Lebanon, Irak, dan beberapa negara lain.

Faktor terakhir penyebab menguatnya Radikalisme-Ekstremisme dari ranah sosial politik menurut Haidar ialah terjadinya musim semi Arab (Arab Spring). Perkembangan musim-semi Arab (Arab Spring) belakangan ini merupakan peristiwa mutakhir yang, sayangnya, justru memperparah kecenderungan ekstremisme dan sikap takfirisme di negara-negara seperti Arab Saudi, Bahrain, dan Suriah. Sebagaimana di Indonesia pasca-Reformasi, demokratisasi yang lahir dari musim semi Arab ini seolaholah seperti membuka 'kotak pandora', yang memungkinkan kelompok-kelompok ekstrim Islam termasuk yang beraspirasi kekerasan, yang tadinya tertahan oleh otoritarianisme yang berkuasa mendapatkan ruang untuk berkembang bebas.

Meskipun akar ideologis gerakan radikalisme dapat diidentifikasi memiliki dua motif utama sebagaimana dipaparkan oleh Haidar Bagir di atas, akan tetapi dari sisi gerakan, kelompok ini memiliki pola yang hampir sama. Hal ini ditegaskan oleh Shireen T. Hunter sebagaimana dikutip Syarkun dan Ghorara bahwa ada enam pola gerakan dan visi yang ingin dicapai oleh kelompok radikalis dalam mewujudkan visi mereka: ${ }^{7}$

Pertama, konsep din wa daulah (agama dan negara). Dalam konsep ini, Islam dipahami sebagai sistem hidup total, yang secara universal dapat diterapkan pada semua keadaan, waktu dan tempat. Pemisahan antara

\footnotetext{
7 Mukhlas Syarkun dan W Ghorara, Dunia Islam dalam
} benturan kepentingan dan Peradaban dalam Negara agama (din) dan negara (daulah) tidak dapat diterima oleh kelompok fundamentalis sehingga agama dan negara dipahami secara integralistik.

Kedua, mereka ingin kembali kepada alQur'an dan Sunnah. Dalam konsepsi ini, umat Islam diperintahkan untuk kembali kepada akar-akar Islam awal dan praktik Nabi SAW yang puritan dalam mencari keaslian (otentisitas) dan pembaruan. Jika umat Islam tidak kembali ke 'jalan yang benar' dari para pendahulu mereka, maka mereka niscaya tidak akan selamat. Mereka kembali kepada alQur'an dan Sunnah dipahami secara skriptual dan totalistik.

Ketiga, puritanisme dan keadilan sosial. Nilai-nilai dan budaya Barat ditolak karena dianggap sebagai sesuatu yang asing bagi Islam. Oleh karena itu, media massa diupayakan untuk menyebarkan nilai-nilai dan praktik Islam yang otentik ketimbang menyebarkan pengaruh-pengaruh budaya asing yang sekuler. Pemahaman ini mensyaratkan adanya penegakan keadilan sosial ekonomi sehingga doktrin tentang zakat sangat ditekankan. Karena dalam hubungannya dengan kebijakan negara, maka dianggap dapat memajukan kesejahteraan sosial dan mampu memperbaiki kesenjangan kelas di kalangan umat.

Keempat, berpegang teguh pada kedaulatan syariat Islam. Tujuan utama umat Islam adalah menegakkan kedaulatan Tuhan di muka bumi ini. Tujuan ini bisa dicapai dengan membangun tatanan Islam (Nizham al-Islam) yang memosisikan syariat sebagai undangundang tertinggi. Dari pemahaman ini, maka agenda formalisasi syariat Islam menjadi entry point bagi terbentuknya negara Islam sehingga syariat Islam benar-benar dapat diperlakukan dalam hukum positif, baik hukum perdata seperti perkawinan, perceraian, waris, maupun hukum jinayat seperti potong tangan dan lain sebagainya.

Kelima, menempatkan jihad sebagai instrumen gerakan. Umat Islam diperintahkan

Tuhan; The Thematic Encyclopedia(Jakarta: SR Ins Publishing, 2004), hal. 491-493 
untuk membangun masyarakat ideal sebagaimana telah digariskan dan sesuai dengan syariat Islam. Oleh sebab itu, diperlukan adanya upaya untuk menghancurkan kehidupan jahiliyah dan menaklukkan kekuasaan-kekuasaan duniawi melalui jihad atau perang suci. Jihad tidak dilakukan dalam pengertian defensif semata, tapi memuat tujuan jihad untuk menaklukkan semua hambatan penyiaran Islam ke seluruh dunia, yang meliputi negara, sistem sosial dan tradisi-tradisi asing.

Keenam, perlawanan terhadap Barat yang hegemonik dan menentang keterlibatan mendalam dari pihak barat untuk urusan dalam negara Islam, seperti yang terjadi di Irak, Libya, Bosnia, Afghanistan dan Palestina. Mereka merasa harus mendeklarasikan perlawanannya terhadap barat karena umat Islam sudah diperlakukan dengan tidak adil, baik secara politik ekonomi, maupun budaya. Dominasi barat atas negara Islam tidak dalam kapasitas saling bekerja sama melainkan memojokkan dan memusuhi. Pada gilirannya, ketidakadilan barat dilawan dengan aksi-aksi kekerasan di berbagai negara, termasuk Indonesia. ${ }^{8}$

\section{Periode Kemunculan Radikalisme \\ Benih-benih awal radikalisme masa nabi Muhammad SAW}

Khawarij diklaim sebagai kelompok pertama dalam Islam yang menggaungkan radikalisme dalam pola gerakan mereka. Meskipun kemunculan Khawarij dipicu persoalan politik pada masa Khalifah Ali sebagaimana akan dipaparkan nanti, tetapi sebenarnya bibit-bibit Khawarij telah ada sebelum konflik politik tersebut, yakni berupa kecenderungan untuk bersikap secara tidak proporsional. Sifat demikian sudah terlihat pada masa Nabi Muhammad. Hal inilah yang oleh Nayif Mahmud Ma'ruf disebut sebagai akar-

\footnotetext{
${ }^{8}$ Lihat juga dalam Pemaparan Dwi Ratnasari, Fundamentalisme..., 46-47

${ }^{9} \mathrm{Ma}$ 'ruf, al-Khawarij..., 14.

${ }^{10}$ Ibid., 14-16
}

akar Khawarij. Menurutnya, hampir semua perawi hadits menyepakati adanya prediksi Nabi Muhammad mengenai kemunculan Khawarij. ${ }^{9}$

Dikisahkan, pada tahun $8 \mathrm{H}(629 \mathrm{M})$ ketika Rasulullah dan pasukan muslim selesai dari Perang Hunain, maka Rasulullah segera membagikan harta rampasan perang kepada orang-orang Islam. Tiba-tiba seseorang dari suku Tamim yang dikenal dengan nama DhualKhuwaysirah mendatangi Rasulullah dan memprotes keras terhadap pembagian rampasan perang yang dilakukan Rasulullah. Ia mengatakan, "Aku tidak melihat engkau telah berbuat adil." Rasulullah kemudian menanggapi, "Apabila tidak ada keadilan padaku, maka pada siapa lagi keadilan itu diperoleh? "Tatkala para shahabat hendak membunuh Dhual-Khuwaysirah, maka Rasulullah melarangnya.

Nama asli Dhual-Khuwaysirah adalah Khurqusibn Zuhayr al-Sa'di. Ia disebut sebagai perintis Khawarij dalam sejarah umat Islam. Dalam perkembangan selanjutnya, Khurqus merupakan pihak yang sangat berperan dalam konspirasi untuk melakukan pembunuhan terhadap Khalifah 'Uthman, serta dalam memimpin pemberontak-pemberontak dari Bashrah yang berakibat fatal bagi 'Uthman. Demikian pula, pada saat terjadinya Perang Siffin, Khurqus termasuk di antara para pemimpin pembelotan terhadap Khalifah 'Ali. Khurqus ikut pergi bersama Khawarij lainnya ke Harura' dan melakukan perlawanan kepada pemerintahan 'Ali dalam Perang Nahrawan, sampai ia menemui kematiannya di tangan pasukan 'Ali. ${ }^{10}$ Selain menunjukkan karakter sikap yang cenderung tidak proporsional ketika menghadapi suatu permasalahan, peristiwa Khurqus yang memprotes pembagian rampasan Perang Hunayn di atas juga memperlihatkan adanya motif ekonomi di balik kemunculan Khawarij semenjak awal. ${ }^{11}$

\footnotetext{
${ }^{11}$ Ahmad Choirul Rofiq, Awal Radikalisme Islam: Penyebab Kemunculan Khawarij (Jurnal Al-Tahrir, Vol. 14, No. 1 Mei 2014), 228-229
} 
Paparan di atas menunjukkan bahwa benih-benih radikalisme Islam telah ada pada masa formasi Islam di mana Rasulullah berdakwah. Adapun motif-motif munculnya gerakan radikalisme Islam ini tidak hanya di latar belakangi aspek teologi semata tetapi juga politik, sosial, dan ekonomi. Bahkan gerakan radikalisme Islam pertama kali muncul dari motivasi ekonomi.

\section{Periode formalisasi Khawarij masa shahabat}

Gerakan dan pemikiran radikal dalam Islam mulai tumbuh pada masa Nabi Saw. Akan tetapi baru mengkristal menjadi sebuah gerakan yang bernafaskan politik pada masa kepemimpinan khalifah Ali. Oleh karena itu, pembahasan kali ini akan mengetengahkan Khawarij sebagai cikal bakal gerakan radikal dalam Islam secara formal.

Salah satu aliran yang tertua dalam Islam ialah yang dinamakan aliran dari golongan Khawarij atau Kharijiyah. Perkataan ini berarti pada mulanya keluar, yakni golongan yang meninggalkan paham-paham yang ada pada waktu itu. Tetapi dengan nama ini terutama dimaksudkan suatu golongan yang terjadi pada waktu peperangan di Siffin pada tahun 657M tidak kurang 12.000 tentara Ali bin Abi Thalib karena perselisihan paham mengenai keangkatannya menjadi Khalifah lalu meninggalkan kesatuan tentara mereka itu dan menyendiri dalam keyakinannya. ${ }^{12}$

Pendapat di kalangan Khawarij ada yang mengatakan bahwa kata Khawarij terambil dari kata yakhruju dalam Surat An-Nisa': 100

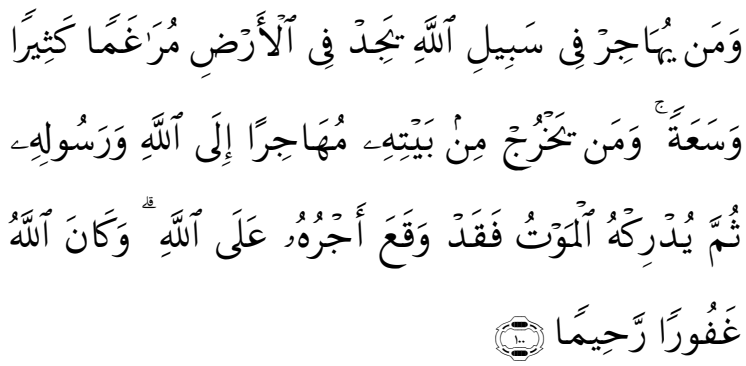

Artinya: "Barangsiapa berhijrah di jalan Allah, niscaya mereka mendapati di muka bumi ini

\footnotetext{
${ }^{12}$ Abu Bakar Atjeh,Ilmu Ketuhanan : Ilmu Kalam (Jakarta: Tinta Mas, 1966), 54.
}

tempat hijrah yang luas dan rizki yang banyak. Barangsiapa keluar dari rumahnya dengan maksud berhijrah kepada Allah dan Rasul-Nya, kemudian kematian menimpanya (sebelum sampai ke tempat yang dituju), Maka sungguh telah tetap pahalanya di sisi Allah. dan adalah Allah Maha Pengampun lagi Maha Penyayang." (An-Nisa':100)

Mereka memaknakan kata yakhruju dalam surat An-Nisa tersebut dengan diri mereka dan mempersamakan posisi yakhruju dengan Muhajirin. Dalam pengertian yang seperti inilah mereka menyebutkan tempattempat yang mereka tuju dengan Muhajar atau Darul Hijrah. ${ }^{13}$

Sebagaimana telah disinggung di muka, bahwa sebenarnya akar pemikiran Khawarij telah muncul ketika nabi Muhammad SAW masih berdakwah yakni tatkala seorang laki-laki dari Bani Tamim yang bernama Quwaishirah melakukan protes terhadap Nabi Muhammad Saw. laki-laki itu menuduh Nabi tidak adil dalam pembagian harta rampasan perang tersebut.

Kemudian peristiwa tahkim yang menjadi momentum lahir dan pecahnya dua kelompok yakni Syi'ah dan Khawarij menjadi kubu yang berlainan karena setelah tahkim Khawarij menjadi sangat membenci Khalifah Ali dan menganggap kepemimpinan Ali tidak sah karena menuruti perbuatan pemberontak (Bughat) Mu'awiyah sehingga muncullah kepermukaan kelompok baru yang bernama Khawarij.

Setelah pengumuman hasil tahkim antara wakil dari Khalifah Ali yakni Abu Musa AlAsy'ari dan wakil dari Mu'awiyah yakni Amr bin Ash yang ternyata merugikan pihak Khalifah Ali -yang Khawarij ada di dalamnyaPenolakan sebagian pasukan Ali terhadap hasil tahkim yang dianggap sebagai tipu daya dari Mu'awiyah dan Amr Ibn Ash semakin menimbulkan perselisihan-perselisihan yang mendalam di pihak khalifah Ali. Pengikut-

\footnotetext{
13 Nouruzzaman Shiddiqi,Syi'ah dan Khawarij dalam Perspektif Sejarah (Yogyakarta: Penerbitan PLP2M, 1985), 5.
} 
pengikut Ali dari kelompok garis keras berpendapat seharusnya Ali memaksa mereka agar kembali kepada keadilan dan kebenaran dan bukan sebaliknya malah mengikuti perbuatan salah. ${ }^{14}$ Hal ini yang kemudian mengakibatkan sebagian dari pengikut Ali memilih untuk memisahkan diri dari pasukan Ali dan pergi menuju Harura dan setelah itu mengangkat Abdullah Ibn Wahab Ar-Rasibi sebagai Khalifah pengganti dari Ali Ibn Abi Thalib yang telah mereka tinggalkan.

Selepas arbitrase tersebut, dapat disimpulkan saat itu terdapat tiga kelompok yakni pendukung Ali yang disebut Syi'ah, Pendukung Mu'awiyah, dan Khawarij yang terpisah dari kedua kelompok di atas. Pada tahun 659 M pasukan Khawarij pimpinan Abdullah Ibn Wahab Ar-Rasibi dapat dihancurkan oleh pasukan Khalifah Ali di tepi Sungai Nahrawan. ${ }^{15}$ Dalam pertempuran tersebut Khawarij mengalami kekalahan total hingga pemimpin-pemimpin mereka gugur di medan perang dan hanya beberapa orang saja yang bisa melarikan diri. Namun, meskipun telah mengalami kekalahan, kaum Khawarij menyusun barisan kembali dan meneruskan perlawanan terhadap kekuasaan Islam resmi baik di zaman Dinasti Umayyah maupun Abbasiyah. Pemegang-pemegang kekuasaan yang ada pada waktu itu mereka anggap telah menyeleweng dari ajaran Islam dan oleh karena itu mesti ditentang dan dijatuhkan. ${ }^{16}$

Dari pemaparan di atas dapat diketahui jika Khawarij merupakan aliran sempalan dalam Islam yang muncul berusaha untuk melakukan revolusi terutama terhadap pemerintahan karena pokok ajaran pertama mereka adalah doktrin politik yakni urusan kekhilafahan saat itu yang menurut mereka para Khalifah setelah tahun ke tujuh pemerintahan Utsman Ibn Affan tidak sejalan lagi dengan Al-Qur'an. Walaupun kemudian pemikiran mereka juga masuk ke

\footnotetext{
${ }^{14}$ Rochimah., et al,Ilmu Kalam (Surabaya: IAIN Sunan Ampel Press, 2011), 28.

15 Ahmad Choirul Rofiq, Sejarah Peradaban Islam: Dari Masa Klasik Hingga Modern (Ponorogo: STAIN Ponorogo Press, 2009), 102.
}

ranah teologi karena mereka melakukan takfir terhadap kelompok yang menjadi lawan pemikiran mereka. Faktor inilah yang menjadikan Khawarij disebut-sebut sebagai aliran garis keras dalam Islam.

\section{Radikalisme Islam Kontemporer}

Pada saat ini, secara sosiologis dapat dikatakan komunitas Khawarij atau setidaknya mereka yang menamakan dirinya kelompok Syurah telah tiada lagi di muka bumi setelah mengalami kekalahan dari pasukan militer Bani Umayyah namun ketika ditelusuri lebih dalam lagi ternyata akar ideologi radikal dari paham Khawarij masih ada dan masih berkembang hingga kini.

Salah satu potongan sejarah yang dapat diajukan sebagai contoh konkret dari tetap berkembangnya paham radikal Khawarij ini adalah seorang Islamis dari Afghanistan Abdullah Azzam. Pada tahun 1987 Abdullah Azzam membuat sebuah polemik dengan menulis sebuah karya tulis berjudul Ilhaq bil Qaafila (Bergabunglah dengan Kafilah). Dalam karyanya itu, Azzam menyerukan kepada kaum Muslim untuk melawan Uni Soviet dengan menyerukan gagasan bahwa kaum muslim di seluruh dunia membentuk masyarakat lintas Negara atau Ummah. Dia berpendapat di mana saja, tanah kaum muslim itu ibarat satu wilayah. Karena itu, mempertahankan Islam di Afghanistan adalah tugas suci agama dan semua orang Islam harus menunaikannya. ${ }^{17}$

Gagasan Abdullah Azzam di atas, tentu bukanlah gagasan yang benar-benar baru dalam gagasan keislaman di era modern saat ini, karena sebagian besar kelompok Islamis (mereka yang menginginkan khilafah Islamiyah) menganggap batas-batas Negara yang ditetapkan saat ini adalah akibat dominasi barat di abad ke 20 yang ditujukan untuk melemahkan posisi Islam. ${ }^{18}$

\footnotetext{
${ }^{16}$ Rochimah., et al, Ilmu Kalam, 32-33.

17 Greg Fealy dan Anthony, Jejak Kafilah: Pengaruh Radikalisme Timur Tengah di Indonesia. terj: Akh Muzakki (Bandung: Mizan, 2007), 18.

${ }^{18}$ Ibid., 20.
} 
Jika kita amati, meskipun dalam konteks yang berbeda, gagasan seperti tersebut di atas memiliki kesamaan dengan konsep yang dikembangkan oleh kelompok Ekstrimis Khawarij yang menggaungkan Dar Al-Islam yang mana mereka menginginkan kesatuan umat Islam di seluruh dunia tanpa adanya batasbatas wilayah geografis dengan membentuk komunitas Islam menjadi satu-kesatuan negara yang berlandaskan keagamaan dan tauhid kepada Allah SWT.

Dari konsep Dar al-Islam tersebut, kemudian muncul pemikiran Dar al-Kufr sebagai anti tesisnya yang merupakan wilayah di luar Dar al-Islam yang mereka klaim sebagai wilayah orang-orang kafir yang halal darah dan hartanya serta harus diperangi.

Ironisnya, paham seperti ini tetap diadopsi oleh sebagian umat muslim yang menginginkan untuk membentuk khilafah Islamiyah dan mengklaim diri sebagai pembawa panji kebenaran karena berpedoman pada wahyu Allah SWT, yakni al-Qur'an. Kelompok ini yang disebut sebagai kelompok fundamentalis Islam. Kelompok yang menginginkan untuk diterapkannya Islam yang menurut mereka murni sebagaimana termaktub di dalam Al-Qur'an dan sesuai dengan ajaran Nabi Muhammad Saw.

Secara teoretik, fundamentalismeradikalisme memang ditandai dengan tiga unsur:

1. Fenomena keagamaan;

2. Penolakan terhadap dunia, sebagai reaksi terhadap perubahan dan kultur yang dipersepsikannya sebagai krisis;

3. Reaksi defensif dengan berupaya mempertahankan atau merestorasi tatanan sosial masa lalu yang diidealkan atau diimajinasikan sebagai paling otentik dan benar. ${ }^{19}$

Untuk unsur pertama dan kedua, mereka kerap mengembangkan etika hukum yang cenderung rigid (kaku), karena memusatkan perhatian pada regulasi hukum yang konkret seperti ketentuan halal, haram dan seterusnya.

\footnotetext{
${ }^{19}$ Mun'im A. Sirry, Membendung Militansi..., 4.

${ }^{20}$ Ibid., 6.
}

Perhatian yang begitu besar pada regulasi kehidupan sehari-hari yang didasarkan pada prinsip-prinsip keagamaan dan kewajiban ritual, menyebabkan pemahaman keagamaan yang dikembangkan bersifat literalis-legalistik. ${ }^{20}$

\section{Mensikapi Radikalisme}

Pemahaman mengenai fundamentalisme radikalisme Islam secara doktrinal sama dengan doktrin Khawarij yang literal-legalistik terhadap al-Qur'an dan regulasi serta ritual agama Islam. Secara ideologi pemahaman ini baik, karena ingin memurnikan Islam dari khurafat atau bahkan syirik. Namun sayangnya metode yang ditempuh pun juga sama yakni perjuangan dengan sikap anarkisme sebagaimana Khawarij. Contoh kongkretnya ialah pengeboman di World Trade Center di Amerika, Bom Bali I dan II di Indonesia, pengeboman J.W Marriot, Gerakan teror ISIS di seluruh dunia sudah cukup merepresentasikan kelompok fundamentalis radikal Islam ini sebagai Khawarij gaya baru di era kontemporer.

Di lain pihak, menarik jika melihat pernyataan yang dilontarkan para pemikir Islam pada dasawarsa 1970an seperti "Islam Yes, Partai Islam No" yang dikemukakan oleh Nurcholis Madjid dan Amien Rais yang sempat memberikan pernyataannya dalam sebuah tulisan ia menyatakan bahwa "Islamic State atau Negara Islam saya kira tidak ada dalam Al-Qur'an maupun Al-Sunnah. Oleh karena itu, tidak ada perintah dalam Islam untuk menegakkan Negara Islam. Yang lebih penting adalah selama suatu negara menjalankan etos Islam, kemudian menegakkan keadilan sosial dan menciptakan suatu masyarakat yang egalitarian, yang jauh dari eksploitasi manusia atas manusia maupun eksploitasi golongan atas golongan lain, berarti menurut Islam sudah dipandang sebagai Negara yang baik. Apalah artinya sebuah negara, kalau ternyata hanya formalitas kosong. ${ }^{21}$

Mencermati pernyataan para cendekiawan muslim di atas dapat kita katakan bahwa sebenarnya mereka menginginkan "kualitas

\footnotetext{
${ }^{21}$ Azyumardi Azra, Menuju Masyarakat Madani: Gagasan, Fakta dan Tantangan (Bandung: Remaja Rosdakarya, 2000), 173-174.
} 
Islam" yang dijunjung dan bukan hanya formalitas tampak yang bisa saja itu hanyalah formalitas kosong. Sebuah negara Islam yang tidak menerapkan prinsip keadilan, egalitarian, menghargai hak asasi manusia maka ia tidak dapat dikatakan sebagai negara yang baik menurut ajaran Islam. Dengan demikian, sebaliknya, perjuangan memurnikan Islam dengan anarkisme seperti pergerakan radikalisme Islam justru membuat Islam tereduksi maknanya di mata khalayak karena akan muncul stigma negatif bahwa Islam adalah agama yang identik dengan kekerasan, vandalisme dan terorisme.

Untuk terakhir kalinya, Bagi kita umat muslim, penting kiranya untuk dipahami mengenai esensi perjuangan Islam yang sesungguhnya yang berlandaskan toleransi berbasis pluralisme seperti yang dicontohkan oleh Nabi Muhammad Saw pada masyarakat Madinah baik pada saat minoritas maupun mayoritas.

\section{Penutup}

Mengaitkan agama dengan ekstrimisme, sesuatu yang secara inheren mengandung hal-hal yang tidak biasa dan seringkali dipandang secara pejorative. Dalam hal ini agama dan ekstrimisme sering dilihat sebagai kontradiktif. Namun demikian, dalam kenyataan sehari-hari, kaitan erat antara agama dan ekstrimisme merupakan hal yang mudah ditemui.

Radikalisme merupakan sebuah sikap ekstrim yang ditunjukkan dalam upaya mempertahankan ideologi. Radikalisme banyak diiringi sikap-sikap ekstrim seperti kekerasan, pemaksaan, dan teror kepada kelompok yang dianggap berlawanan dengan ideologi mereka.

\section{Daftar Pustaka}

Atjeh, Abu Bakar.Ilmu Ketuhanan: Ilmu Kalam. Jakarta: Tinta Mas, 1966.

Azra, Azyumardi.Menuju Masyarakat Madani: Gagasan, Fakta dan Tantangan. Bandung: Remaja Rosdakarya, 2000.

Bagir, Hadir.Islam Tuhan, Islam Manusia: Agama dan Spiritualitas di Zaman Kacau. Bandung: Mizan, 2017.

Choirul Rofiq, Ahmad.Awal Radikalisme Islam: Penyebab Kemunculan Khawarij. Jurnal Al-Tahrir, Vol. 14, No. 1 Mei 2014.

------.Sejarah Peradaban Islam: Dari Masa Klasik Hingga Modern. Ponorogo: STAIN Ponorogo Press, 2009.

Fealy, Greg dan Anthony.Jejak Kafilah: Pengaruh Radikalisme Timur Tengah di Indonesia. terj: Akh Muzakki. Bandung: Mizan, 2007.

Ma'ruf, Nayif Mahmud. Al-Khawarij fial- 'Asr alUmawi. Beirut: Dar al-Tali'ah, 1994.

Munir Mulkhan, Abdul.Sufi Pinggiran: Menembus Batas-Batas. Yogyakarta: Kanisius, 2007.

Ratnasari, Dwi.Fundamentalisme Islam. Jurnal KomunikaVol.4 No.1 Januari-Juni 2010.

Rochimah., et al, Ilmu Kalam (Surabaya: IAIN Sunan Ampel Press, 2011), 28.

Shiddiqi,Nouruzzaman. Syi'ah dan Khawarij dalam Perspektif Sejarah. Yogyakarta: Penerbitan PLP2M, 1985.

Sirry, A Mun'im.Membendung Militansi Agama: Iman dan Politik dalam Masyarakat Modern. Jakarta: Erlangga, 2003. 
Syarkun, Mukhlas dan Ghorara, W. Dunia Islam dalam Benturan Kepentingan dan Peradaban dalam Negara Tuhan; The Thematic Encyclopedia. Jakarta: SR Ins Publishing, 2004.
Wirawan Sarwono, Sarlito. Terorisme di Indonesia dalam Tinjauan Psikologis. Jakarta: Pustaka Alvabet, 2012.

Copyright (C) 2018 Journal Dirasah: Vol. 1, No. 2, August 2018, p-ISSN: 2615-0212, e-ISSN; 26212838 Copyright rests with the authors

Copyright of Jurnal Dirasah is the property of Jurnal Dirasah and its content may not be copied or emailed to multiple sites or posted to a listserv without the copyright holder's express written permission. However, users may print, download, or email articles for individual use. https://ejournal.stisfa-kediri.ac.id/index.php/dirasah 